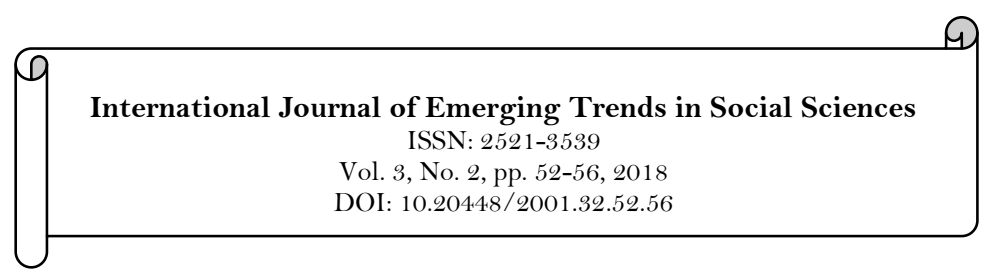

\title{
Attitudinal Disposition of Students Towards the Personality Traits of Counsellors. A Case Study of Public Secondary Schools in Delta State, Nigeria
}

\author{
Jude J. Obiunu ${ }^{12}$ \\ Ozuri Rachael $^{2}$
}

'Delta State University, Abraka, Nigeria.

Email:obiumu@yahoo.com

${ }^{2}$ Department of Guidance and Counselling, Faculty of Education, Nigeria.

Email:rachael.britney@yahoo.com

Abstract
The study examined attitudinal disposition of students towards the
personality traits of counsellors, using a case study of Public

\section{Introduction}

Students in secondary schools have different attitudinal disposition towards the personality traits of the guidance counsellor. These attitudes determine whether they will be well disposed towards counselling services or not. These attitudes also affect their behaviour, academic performance and everyday experiences as well as their personality. The term attitude refers to an inner feeling manifested by overt behaviour. The attitude of a person beautifies every aspects of the individual's life. It is like the mind's paint brush which can paint and give a pleasant picture of everything in one's life in bright vibrant colours. The word disposition is the capacity of the individual to react either positively or negatively towards a person or situation. Therefore attitudinal disposition of a person refers to how individuals perceives themselves and the other people either positively or negatively. Student's attitudinal disposition towards the personality traits of the professional counsellor in the school system is an important factor because it helps to determine the outcome of the counselling process (Republic of Kenya, 2004). Students are easily influenced by one who listens to them actively, understands their feelings with empathy, and is genuinely involved in assisting them (Mutie \& Ndambuki, 1999). 
A counsellor is one who is trained to assist students in resolving their educational, vocational and personal-social problems with the pleasant professional qualities of empathy, showing warmth and understanding, unconditional positive regard, friendliness, love and respect. A counsellor must be able to show a positive, unconditional positive regard for the wellbeing of his clients in order to attain a successful counselling therapeutic relationship. A good counselling relationship should be able to create an avenue for respect, warmth, love, commitment and a non-threatening environment. This create opportunity for clients to freely express themselves, their thoughts, feelings, experiences without withholding anything. If all these attributes of the counsellor are not present, the client will find it difficult to approach the counsellor or to even share his problems with the counsellor and this will alter the major goals of counselling because counselling is aimed at helping the clients to achieve a desirable change of behaviour.

The increased rate of indiscipline and many anti-social behaviours in secondary schools in Nigeria, such as psychotic drug and substance abuse, anger, aggression, riots, incessant protest, cultism, sexually transmitted diseases, teenage pregnancies, poor academic performance in the school systems, may be an indication that the students are not approaching the counsellor for help in order for the guidance and counselling services to be rendered due to their negative attitudinal disposition towards the personality traits of the counsellor. The efficiency and success of any guidance and counselling service has been attributed largely to the view points and opinion of students towards such a service (Form, 1953). Student's attitudes which reflects these opinions are indices of their willingness or otherwise to accept, patronize or utilize counselling services. Although attitudes generally have cognitive, affective and behavioural characteristics, in this study, it has been found convenient to conceptualize counselees' attitudes as a function of individual perception. Herman (1971) reported that students attitude to counselling relates to a range of factors, chief among them being individual perception. Burk and Bryan (1979) add that if the perception of students towards the counsellor and its counselling services is poor, it is likely to elicit negative attitudinal response and result in a rejection of its programmes.

An educational or school counsellor spends time in developing strategies which helps students develop their skills and also leads to their growth and development. This enables the students acquire and develop whatever positive qualities they require to function well in society. The counsellor ensures maximum utilization of the relationship with the students to provide a more comprehensive adult model for the development of self-concepts and meaningful activities like orientation, in which the matured students can also contribute to the development of confidence and self- reliance in others. Also, specific counselling programmes for the development of social skills are provided to equip students with what they need to cope with developmental tasks required of them during this adolescent period. Furthermore, the counsellor ensures efficient utilization of the school society or culture in other to promote attitudes consistent with good mental health practices (Bair, 2003). If the counsellor exhibits or portrays a poor personality traits towards the students, students are less likely to visit the counsellor and to seek for assistance in future times or to accept the counsellor's services. Counsellors play an important role in the student's life and it is therefore important that they exhibit positive qualities of a professional counsellor instead of being rude and biased to students with a corresponding consequence of poor decision making among the students.

There are different guidance services that are provided to students which aid them in finding adequate solutions to their many problems within and outside the school system. Makinde (1994) further posits that guidance services helps in giving direction and facilitation of behaviour change in the students which leads to a proper adjustment in all ramifications of the students' lives. Counselling is a type of guidance services that involves interaction between the counsellor and the students (clients) which helps to solve their problems and to equip them with the necessary skills in solving other future related problems. It also helps to prevent frustration, restore self confidence, self-understanding and educate them on the tasks necessary for good student growth and development. Counselling therefore facilitates a favourable atmosphere for healthier growth, development and correction of antisocial behaviour Makinde (1994). Guidance and counselling is seen as the third force in education which is in line with instructions and adequate solution to problems. It is also an integral part of the educational system. The programmes of guidance and counselling in the school systems are designed to address the psychological, physical, emotional, social, vocational and academic challenges of adolescent students which in turn enhance the teaching/learning process for maximum fulfilment of the goals of education.

Nwachukwu (2007) identified the services which includes, educational services, information services, placement services, appraisal services, vocational guidance services, counselling services, referral services, evaluation, follow-up, consultancy and research services. It is expected that all these services is to be provided in the school and absence of these services brings about the prevalence of crimes, aggression, violent acts, vandalization of school properties, cultism, incessant protest, riots, wrong career choice, and wrong subject combination among other issues.

A reliable assessment of the attitudinal disposition of students towards the counsellor and the guidance services has derived importance from the assumption that students are the major recipients of guidance and counselling services in the academic environment. It is believed that the success of any programme in school lies on the students' attitude towards it and the way they accept the counsellor. The perception of students 
towards the counsellor determines to some degree the way students respond and perceive guidance and counselling services. It is therefore important to investigate student's attitudinal disposition towards the personality traits of the counsellor.

\subsection{Statement of the Problem}

No doubt, the counsellor occupies a very strategic position in any educational system and this has been noticed by the Federal Government and that is why the need for guidance and counselling services in the national policy on education (6-3-3-4) system is being re-emphasized. Therefore the counsellor's attributes are paramount to the achievement of the goals of counselling, It is also necessary as noted from the stance of the Federal Ministry of Education that counsellors should operate on full-time basis. More so principals and teachers and other staff of the school system are also aware of the counsellor's roles, functions and services. Despite this fact, it has been observed that in some schools, students rarely seize this golden opportunity given to them to better their lives through proper guidance and counselling. This is because of their perception about the qualities of the counsellor and the way the counsellor behaves and react to their individual needs.

It was also discovered that many school students easily conform to peer pressure and engage in different forms of antisocial behaviour and other acts of indiscipline in the school system and all these may be associated to their poor perception towards the counsellor's attributes and the guidance services. Thus in this era of student extremism, activism and cultism in our schools and campuses, there is increasing pressure on school counsellors to justify their relevance by designing appropriate and proven programmes to meet the challenges posed by these negative tendencies. Violent and revolutionary student behaviour gives birth to social problems that culminate in rape, murder, extortion, destruction of property, insecurity and general breakdown of law and order. Many people argue that counselling when properly adapted has a potential capacity to mediate students' excesses seen largely as a manifestation of lack of self-awareness, confused identity and personality maladjustment (Denga, 2001). It is therefore important for counsellors to show good attributes to the students (so that they can be easily assessed) such as empathy, love and understanding, respect, unconditional positive regard. It is on this basis that this study intends to investigate the attitudinal disposition of students towards the personality traits of counsellors in Delta State.

\subsection{Research Questions}

What is the attitudinal disposition of students towards the personality traits of the counsellor?.

\subsection{Hypotheses}

The following hypotheses were formulated to guide the study and were tested at 0.05 level of significance.

Ho1: There is no significant difference in the attitudinal disposition of students towards the personality traits of the counsellor based on gender.

Ho2: There is no significant difference in the attitudinal disposition of students towards the personal traits of the counsellor based on location.

\section{Methodology}

The research design for this study is the descriptive survey design. The population of this study comprises of all the public senior secondary schools in Delta Central Senatorial District of Delta State. 2000 students were used as the sample for this study using the stratified random sampling technique and the simple random sampling technique. An adapted questionnaire titled Attitudinal Disposition of Students towards the Personality Traits of Counsellors (ADSPTC) was used for data collection. The instrument consisted of two sections. Section one focused on students' demographic data such as gender and location, while section two consists of 20 items used to elicit responses from students on their attitudinal disposition towards the personality traits of counsellors. Their responses were made on a four point likert scale with strongly agree carrying 4points, agree 3 points, disagree 2 points and strongly disagree 1 point. The instrument was validated and had a reliability level of 0.85 . This means that the instrument is reliable for the study. The data collected were analyzed using simple percentage, mean, standard deviation and t-test statistics of independent sample at 0.05 level of significance.

\section{Results}

Research Question 1: What is the attitudinal disposition of students towards the personality traits of the counsellor? 
Table-1. Mean rating of the attitude of students towards the personality traits of the counsellor.

\begin{tabular}{l|l|l|l|l|l}
\hline $\mathbf{S} / \mathbf{N}$ & $\begin{array}{l}\text { Attitude of Students towards the Personality Traits } \\
\text { of the Counsellor }\end{array}$ & $\mathbf{N}$ & $\mathbf{M e a n}$ & $\mathbf{S D}$ & Remark \\
\hline 1 & $\begin{array}{l}\text { Counsellor shows adequate concern about client } \\
\text { problems }\end{array}$ & 2000 & 1.62 & 0.84 & Low \\
\hline 2 & Counsellor talks to students calmly & 2000 & 1.69 & 0.91 & Low \\
\hline 3 & Counsellor is pleasant and friendly & 2000 & 2.15 & 1.05 & Low \\
\hline 4 & Counsellor exhibit warmth towards students & 2000 & 1.71 & 0.91 & Low \\
\hline 5 & Counsellor shows empathy towards students/clients & 2000 & 1.82 & 0.98 & Low \\
\hline 6 & $\begin{array}{l}\text { Counsellors shows love and understanding towards her } \\
\text { students/clients }\end{array}$ & 2000 & 2.43 & 1.02 & Low \\
\hline 7 & Counsellor is a good listener & 2000 & 1.38 & 0.76 & Low \\
\hline 8 & Counsellor attends to clients promptly & 2000 & 1.43 & 0.80 & Low \\
\hline 9 & Counsellor has a stable temperament & 2000 & 1.66 & 0.93 & Low \\
\hline 10 & Counsellor is likeable and approachable & 2000 & 1.89 & 1.02 & Low \\
\hline 11 & Counsellor accepts a client as he is and he is not biased & 2000 & 1.48 & 0.77 & Low \\
\hline 12 & Counsellor is genuine in his propositions to clients & 2000 & 1.56 & 0.83 & Low \\
\hline 14 & $\begin{array}{l}\text { Counsellor readily offers practical and concrete hints that } \\
\text { are helpful in decision making to client }\end{array}$ & 2000 & 1.8 & 0.99 & Low \\
\hline 15 & Counsellor appreciates clients' feeling & 2000 & 1.48 & 0.79 & Low \\
\hline 16 & Counsellor is trustworthy and humble & 2000 & 1.59 & 0.88 & Low \\
\hline 17 & Counsellor protects the privacy of clients & 2000 & 2.11 & 1.05 & Low \\
\hline 18 & Counsellor show a great level of self-understanding & 2000 & 2.11 & 1.07 & Low \\
\hline 19 & $\begin{array}{l}\text { Counsellor respects the worth and dignity of her clients } \\
\text { or students }\end{array}$ & 2000 & 1.67 & 0.90 & Low \\
\hline
\end{tabular}

From the table above, it shows that student's attitudinal disposition towards the personality traits of the counsellor is negative. This is because the mean rating of all the items are less than 2.50 cut off point

\subsection{Analysis of Hypotheses}

Hypothesis 1: There is no significant difference in the attitude of male and female students towards the personality traits of the counsellor

Table-2. T-test analysis of the difference in the attitude of male and female students towards the personality traits of the counsellor.

\begin{tabular}{l|l|l|l|l|l|l}
\hline Gender & N & Mean & SD & t & P & Decision \\
\cline { 1 - 3 } & 878 & 1.80 & 0.41 & 1.15 & 0.25 & Not Significant \\
\cline { 1 - 3 } & 1122 & 1.78 & 0.41 & & & \\
\hline
\end{tabular}

The table above shows that $t=1.15, \mathrm{p} \geq 0.05$, hence the null hypothesis is retained. This means that there is no significant difference between the attitudinal disposition of male and female students towards the personality traits of the counsellor.

Hypothesis 2: There is no significant difference in the attitudinal disposition of urban and rural students towards the personality traits of the counsellor

Table-3. T-test analysis of the difference in the attitudinal disposition of urban and rural students towards the personality traits of the counsellor.

\begin{tabular}{l|l|l|l|l|l|l}
\hline Location & $\mathbf{N}$ & Mean & SD & T & P & Decision \\
\cline { 1 - 4 } Urban & 1275 & 1.82 & 0.41 & 3.89 & 0.000 & Significant \\
\cline { 1 - 4 } & 725 & 1.74 & 0.40 & & & \\
\hline
\end{tabular}

Decisions on hypotheses were made based on 0.05 level of significance. i.e. when $p>0.05=$ accept null hypothesis, when $p \leq 0.05$, reject null hypothesis (my interpretation).

The table above revealed that that $\mathrm{t}$ value of $3.80, \mathrm{p}$ value of 0.000 is lesser than 0.05 , hence the null hypothesis is rejected. This implies that there is a significant difference between the attitudinal disposition of urban and rural students towards the personality traits of the counsellor in favour of students from urban area. Urban area has a higher negative attitude towards the personality traits of the counsellor even though the attitude is negative, is still higher than that of the rural students. 


\section{Discussion of Findings}

The result above revealed that the attitudinal dispositions of students towards the personality traits of the counsellor is negative. This implies that students perceives the counsellors in the school system as one who does not exhibit the professional attributes of the counsellor and that is the reason why they don't approach the counsellor to help them resolve their educational, vocational and personal social problems. This finding is consistent with the work of Ubana (2008) which revealed that the attitude of students towards guidance and counselling is negative and will invariably affect the student's attitudinal disposition towards the counsellor's personality trait. When students don't approach the counsellor for help, they will not also accept the services of the counsellor and this is the reason why there is an increase rate of examination malpractice, bullying, truancy and other academic problems in the educational setup. These students go to their peers to seek advice from them. This finding is also supported by the work of Perham and Tinsely (1985) who opined that students prefer to seek assistance from their friends rather than from the counsellor.

The second finding revealed that there is no significant difference in the attitudinal disposition of students towards the personality traits of the counsellor based on gender. This implies that male and female students have a negative attitudinal disposition towards the personality traits of the counsellor. This finding agrees with Musgrove (1973) which states that there is no significant difference in the attitude of students towards guidance and counselling services based on gender.

The last finding revealed that there is a significant difference between the attitudinal disposition of urban and rural students towards the personality traits of the counsellor. Students from urban area have a higher level of negative attitude towards the personality traits of the counsellor, in comparison to that of the rural students. This finding contradicts the work of Dondo (2004) which states that student's from rural schools uphold the importance of counselling and guidance in enhancing their moral values. The differences could be due to the nature of the study and the location of the study.

\section{Conclusion}

From the findings above, it was concluded that students in Delta State have a negative attitudinal disposition towards the personality traits of the counsellors, also there is no significant difference in the attitudinal disposition of male and female students towards the personality traits of the counsellor. Furthermore, there is a significant difference in the attitudinal disposition of urban and rural students towards the personality traits if the counsellor.

\section{Recommendation}

Counsellors should exhibit the professional qualities such as kindness, empathy, unconditional positive regard, genuiness, patience and love towards the students, counsellors should not be biased in rendering their services and should accept every students unconditionally irrespective of gender and location.

\section{References}

Bair, D. (2003). Jung: A biography. New York: Back Bay Books, Little, Brown, \& Co.

Burk, A., \& Bryan, H. G. (1979). Attitudes of university students and staff to students. Counselling and Research Unit Bulletin, 16, 188-124.

Denga, D. I. (2001). Guidance and counselling in school and non school settings (2nd ed.). Port Harcourt: Double Diamond Publications.

Dondo, M. (2004). Guidance and counselling for schools and colleges. Nairobi: Barclay Christian Publishers.

Form, A. J. (1953). Measurement of students' attitudes towards counselling services. Personal and Guidance Journal, 37, 2787.

Herman, R. C. (1971). Client assessment of a university. Personal and Guidance Journal of Psychology, 18(5), 490-496.

Makinde, O. (1994). Foundations of guidance and counselling. London: Macmillan Publishers Ltd.

Musgrove, W. J. (1973). A survey of high school students' attitudes toward guidance services. Journal of the Student Personnel Association of Teacher Education, 12(1), 25 -31.

Mutie, E. K., \& Ndambuki, P. (1999). Guidance and counseling for schools and colleges. Nairobi: Oxford University Press.

Nwachukwu, D. N. (2007). The teacher counsellor for today's school. Calabar: University of Calabar Press.

Perham, G., \& Tinsely, J. (1985). College students seeking help preferences. Journal of Counseling Psychology, 1(29), 523 533.

Republic of Kenya. (2004). Guidance and counseling: Module for primary school teachers. Nairobi: Government Printers.

Ubana, A. N. (2008). Attitude of secondary school students towards guidance and counselling services in Yakurr local government area in Cross River State. An Unpublished B.Ed Thesis, Cross River University of Technology Calabar. 